\title{
Project Reports
}

Digitization of Syriac Books and Other Holdings at The Catholic University of America

\section{Monica J. Blanchard, The Catholic University of America}

This past year The Catholic University of America Libraries, in cooperation with Beth Mardutho: The Syriac Institute, and Brigham Young University's Institute for the Study and Preservation of Ancient Religious Texts (ISPART), digitized some of the Syriac materials (books, manuscripts, maps, photographs, and other documents) at CUA. This was part of Beth Mardutho's larger venture to establish an Internet digital library of e-books for Syriac studies: eBeth Arké: the Syriac Digital Library. It also was part of a related venture for a Web-based Eastern Christian Reference Library by Brigham Young University.

Between March and August 2004 the CUA team scanned 669 Syriac materials, for a total of 85,389 images, including 53,745 tiff images in black \& white, greyscale, and color, as well as 31,644 color jpeg images. Scanned materials include $17^{\text {th }}$-early $20^{\text {th }}$ century liturgical, theological, historical, and hagiographical works, as well as grammars and dictionaries.

The groundwork for the CUA Syriac digital project began in June 20, 2001 when representatives of CUA, BYU, and Beth Mardutho met to discuss digital library initiatives. I was asked to serve as the local CUA project manager. There were two initial stumbling blocks. The university's Syriac collections are extensive, but they are largely uncataloged and not easily accessible. Also, Mullen Library, which houses the Syriac collections, was scheduled for a major building renovation. Project office space was not available.

The first task of the CUA Syriac Digital Project was to make a bibliographic survey of the Syriac collections. Fr. Matthew Streett, a doctoral candidate in Biblical Studies at CUA, was appointed Project Bibliographer. He compiled a 400 page online bibliography of Syriac materials in the Semitics/ICOR library (035 Mullen), the main repository for CUA's Syriac holdings. This bibliography became an important selection tool and finding aid. 
In January 2004 space suddenly became available in Mullen Library. Beth Mardutho and BYU rearranged their scanning priorities to take advantage of a five month window of opportunity (March-August, 2004) for the Syriac Digital Project. The first Beth Mardutho imaging workstation began operation at CUA on March 6, followed on March 22 by the BYU imaging workstation, and on April 24 by a second Beth Mardutho imaging workstation. The Project shut down on August 15, when renovation work resumed in the building.

Beth Mardutho and BYU provided the equipment, the initial training, and the funds for staff hired at CUA. CUA provided local project management, office space, and the Syriac resources.

A staff of 15 technicians was assembled from the CUA Libraries, the School of Library and Information Science, and from graduate academic departments and programs with an interest in Syriac (Semitics, Early Christian Studies, Biblical Studies, Medieval and Byzantine Studies. Volunteers from the Syriac Church communities also helped. Technicians with Syriac and Arabic language skills entered metadata information in Arabic and Syriac into the Beth Mardutho metadata database; they also dealt with pagination and bibliographic issues in these languages. Technicians with library skills worked with fragile and valuable materials requiring special handling. All the student technicians had good computer skills and an eye for detail — these proved to be the most important job assets. Two of the technicians, Jonathan Loopstra (for Beth Mardutho) and Diana Jill Kirby (for BYU), served as quality assurance heads. Both had previous quality assurance experience. The CUA team established work flow patterns and scanning procedures for the project. The team also prepared basic operations manuals which may be helpful for other institutions participating in eBeth Arké. 
BYU-CUA Eastern Christian Research Library

\section{KRISTIAN S. HEAL, BRIGHAM YOUNG UNIVERSITY}

[1] A great number of essential Syriac texts are not readily available to scholars, even in some of the world's great research libraries. In order to remedy this situation, Brigham Young University has joined with The Catholic University of America to undertake a joint project to produce an on-line research collection for Syriac studies. What follows is a report of the work carried out so far. For further details please consult the project website (http://cpart.byu.edu/ECRL).

\section{SCOPE OF THE PROJECT}

[2] This project aims to build an Eastern Christian Research Library (the Library) of key editions and instruments de travail published before 1930. The Library is primarily intended to be a resource for scholars engaged in textual and manuscript research in the major Eastern Christian languages. The Syriac section of the Library will be populated first, under the editorship of Dr. David Taylor. ${ }^{1}$ Because of its focus, the Syriac section will include only a fraction of the literature published on Syriac studies before 1930. The Library is therefore intended to complement and support Beth Mardutho's more comprehensive eBethArké project (http://www. bethmardutho.org/ebetharke). ${ }^{2}$

\section{SyRIAC SECTION-PHASE 1}

Dr. Taylor has set the basic parameters of the Syriac section and drawn up a preliminary bibliography of volumes for inclusion (see project website). Renovations to CUA's Mullen Library created an opportunity in the summer of 2004 to begin populating the library with rare and important works. The richness of the Syriac holdings at CUA cannot be overestimated, nor can the kindness and

1 The Coptic section, under the editorship of Dr. Janet Timbie, is in its early stages. Pending available resources, it is hoped that the Library we expand to include Armenian, Christian Arabic, Ethiopic, and Georgian sections.

${ }^{2}$ BYU and CUA are library partners of eBethArké and are actively supporting this important initiative. 
competence of the collection's distinguished librarian, Dr. Monica Blanchard. Under her direction, and with the help of competent student workers, 157 individual titles were scanned over a relatively brief period.

Images at CUA were captured on a Zeutschel Omniscan 10000 TT color book scanner tethered to a Windows PC, with a second PC used for proofing and data backup, which was done on DVD. The Zeutschel imaging system is the best of its kind, capable of producing very high resolution scans with high color accuracy, yet with a minimum of stress to the book or manuscript. Images were captured at $600 \mathrm{dpi}$, resulting in (e.g.) a 70 megapixel image for a two-page capture of a 9"x11" book.

The next stage is to make the images accessible. Images are being cropped, rotated, and resized in post-processing and prepared for delivery as one of BYU library's online collections. The collection will be freely accessible to all. The books will be mounted on the web and made accessible through the ContentDM image delivery system. The unprocessed and processed images will also be archived by the library for future usage. The first phase of the Syriac collection will be made available over the course of the next year. Preference will be given to high demand items. The state of the collection will be recorded on the project website and announced periodically via the Hugoye mailing list. We hope this will be a useful resource and benefit scholars working in the field. 
Vatican Syriac Manuscripts, Volume 1

\section{KRISTIAN S. HEAL, BRIGHAM YOUNG UNIVERSITY}

[1] This report marks the publication on DVD-ROM of a collection of thirty-three electronic facsimiles of Syriac manuscripts from the Vatican Library. Further details, including how to order the DVDROM are available at the project's website (http:// cpart.byu.edu/Vatican). ${ }^{1}$

\section{BACKGROUND}

[2] This project is focused on the Syriac manuscripts of the Biblioteca Apostolica Vaticana, a collection that extends to over 850 manuscripts, including the collection of 181 formerly at the Borgian Museum. ${ }^{2}$ The collection began to grow significantly in the early $18^{\text {th }}$ century. Pope Clement XI encouraged a number of successful missions to Egypt and elsewhere in the Middle East to acquire manuscripts. Through the efforts of Elias Assemani, his cousin J. S. Assemani, and Gabriel Eva, some of the most significant of all surviving Syriac manuscripts were acquired in this period.

In 1999 Mar Bawai Soro, a bishop of the Assyrian Church of the East, began discussions with the Vatican Library to make their Syriac collections more accessible both to scholars as well as to the communities who produced these texts. Mar Bawai approached Brigham Young University to be a partner in the project, a proposal that was eagerly received. The idea of a pilot project was formulated by the parties and a contract between BYU and the Vatican Library was signed in early 2000. The manuscript photography was undertaken in two phases, one in June 2000 and another in April 2002.

${ }^{1}$ An interim report for this project was published in "The Digitizing of Selected Syriac MSS in the Vatican Apostolic Library," Hugoye: Journal of Syriac Studies vol. 3, no. 3 (2000). The project began under the direction of Dr. E. Jan Wilson.

${ }^{2}$ For further bibliography on the Vatican Library's Syriac collection see, A. Desreumaux and F. Briquel-Chantonnet, Répertoire des Bibliothèques et des Catalogues de Manuscrits Syriaques (Paris: Editions du Centre national de la recherche scientifique, 1991). 


\section{REPORT}

The project was formulated with the kind assistance of academics working in the field of Syriac studies and was carried out with direction from a small advisory group (Professor Sidney Griffith, Professor Samir Khalil and Mar Bawai Soro (Assyrian Church of the East)). Dr. Sebastian Brock made an initial assessment of the collection, which resulted in a list of especially significant manuscripts (Appendix 1 below). From this list, Mar Bawai Soro selected 28 for a pilot project, which was later supplemented by 5 additional manuscripts.

The project proposal was originally modeled on BYU's Dead Sea Scrolls database. This database gives precedence to a searchable transcription of the scrolls and includes both the images and corresponding translations in the final product. Plans were therefore made to transcribe the manuscripts, and two teams were put in place, one for manuscripts written in the East Syriac script and one for manuscripts written in the Estrangelo and Serto scripts. This proved to be a not altogether appropriate model and a new approach was formulated as will be discussed below.

The photography was undertaken in two stages. In both stages we were able to set up a controlled studio environment, including camera stands, full lighting sets and back-up systems. The first stage of photography (June 2000) was undertaken using a Kodak MegaPlus camera with an array of $2 \times 3 \mathrm{k}$, producing 6 megapixal images. These grey-scale images were stored immediately after capture on Mitsui Gold CDs. The archival copies are in TIFF format and are approximately 6 megabytes each. A second set of these CDs was made on returning to BYU. In the second stage of photography (April 2002) we used a Canon EOS 1D, which captured full color 4 megapixal images. These images were also archived in uncompressed TIFF format, with each image being approximately 25 megabytes in size.

In the two stages of photography we captured a total of 14,700 images, which occupy 196 CD-ROMS, with a total archival data size of 117,600 megabytes. One manuscript alone, Vatican Syriac 117 , required $50 \mathrm{CD}-\mathrm{ROMS}$ to produce the archival copy.

Further to the conventional photography we also undertook a series of tests using Multi-Spectral Imaging on Vatican Syriac 110, $114,117,147,252$, and 586. Thus far these tests have produced no beneficial results, though further analysis of the data is underway. 
All digital photographs require processing. Furthermore, the uncompressed images were prohibitively large to view easily, so some compression was necessary. We opted for JPEG compression at a rate of $50 \%$. We considered this to be optimal, since it produced a significantly smaller image with very little degradation of image quality. An initial stage of processing was necessary prior to compressing the images. In most cases the manuscripts were captured in a double page opening. We therefore cropped all of the images down to a single page and ran each image through a series of adjustments in Adobe Photoshop; a process that was successfully automated. The images were then brought into the Adobe PDF format for presentation. Further image manipulation is possible, though we did not consider the necessary expenditure of time to be prudent. Scholars who wish to undertake more sophisticated manipulation of particular manuscripts can request copies of the uncompressed images.

After a number of meetings with digital projects specialists at the BYU library, it was determined that the Adobe PDF format would be the best format to deliver the images. Though initial plans had pointed towards the use of BYU's own WordCruncher program as the best finished format, it quickly became clear that such an approach was impractical. A number of other image-only solutions were considered, but each of these proved less desirable than Adobe PDF.

The advantages of the PDF format are numerous. In particular, because Adobe PDF was designed to view continuous documents and books, it reproduces an environment that is familiar to readers. One can navigate easily between pages, magnify the images, and arrange the screen in such a way that the images may be viewed simultaneously with other programs. It is also becoming a standard document format in both a business and academic context, with many libraries delivering documents in this format. Also, the Adobe Reader is freely available and constantly being improved by the developer.

In order to make a number of PDF files available on the same DVD, we designed and developed a simple interface which runs immediately on inserting the disc. This interface includes an overview of the project and a table of contents. The table of contents contains links to thirty-three PDF files. Each of these files contains an electronic facsimile of a single Vatican manuscript. The 
PDF files are identified by the manuscript number and a brief description. When the file opens, the first thing shown is an index to the manuscripts prepared on the basis of the existing catalogs. To these basic entries we have added references to editions and standard reference works that have been published subsequent to the original catalog entry. Each entry in the index also serves as a hyperlink. Clicking on an entry immediately takes one to the place in the manuscript to which that index entry refers. Also, for ease of reference we have included the original catalog entry immediately after our index.

\section{General Assessment of THE Project}

[13] This project has been undertaken over a four year period. During that time the objectives of the project have shifted and settled. The initial project description was modeled on our successful Dead Sea Scrolls project and focused on the utility of searchable transcribed texts. The Dead Sea Scrolls database contains about 1300 images, many of which contain only fragmentary texts. This project involves a corpus ten times that size. In addition to the difference in size and concomitant feasibility of such a project, there was the question of desirability and optimal presentation. It soon became clear from consultation with other scholars that the most needed result from this project was a usable set of images from the manuscripts. In other words, scholars wanted electronic facsimiles. There is of course a great desire for a database of searchable texts, but such a project needs to be organized along the lines of a discrete corpus of a single author, and based on critical editions rather than on an eclectic collection of manuscripts. We have therefore reconfigured the project to actively meet the needs of the field, and intend to re-purpose the extensive transcription work that we have undertaken.

Not only have our objectives been clarified, but we have also seen the technological landscape entirely shift. When we began this project, we used specialist industrial grey-scale digital cameras. In the intervening years, this equipment has been thoroughly superceded. The second stage of photography used the best available professional color digital SLR. This camera has also been superceded several times over. Though technology will of course continue to improve, we think we have now reached the stage where the available technology will produce images of an optimal 
quality. It is also clear that we will only want to take color images in future projects and that it may be desirable for some of the manuscripts to be re-imaged in color. Nevertheless, with respect to the necessary technology this is a highly propitious time to continue this important project.

\section{APPENDIX 1}

\section{Significant Syriac Manuscripts in the Vatican Library}

Prepared by Sebastian Brock

Items in italic are included in Volume 1.

\section{Biblical manuscripts}

1. Vat. Syr. 1: Pentateuch, 928/9 A.D.

2. Vat. Syr. 12: Gospels, 548

3. Vat. Syr. 13: Gospels, 736

4. Vat. Syr. 14: Gospels, 956

5. Vat. Syr. 16: New Testament, 13th Cent.

6. Vat. Syr. 18: John, Harklean, + Gospel lectionary, 1481

7. Vat. Syr. 19: Christian Palestinian Aramaic Gospel lectionary, 1030

8. Vat. Syr. 20: Melkite Gospel lectionary, 1215

9. Vat. Syr. 21: Melkite Lectionary for Acts and Epistles, 1162

10. Vat. Syr. 22: Lectionary for Epistles (written in India), 1301

11. Vat. Syr. 23: Syriac-Arabic Lectionary for Epistles, $12^{\text {th }}$ century

12. Vat. Syr. 24: OT lectionary, $13^{\text {th }}$ century

13. Vat. Syr. 152: OT, Masora, 979/80

14. Vat. Syr. 266: NT, 7th cent.

15. Vat. Syr. 267: Harklean Gospels, $8^{\text {th }}$ cent.

16. Vat. Syr. 268: Harklean Gospels, 859

17. Vat. Syr. 273: Gospels, $7^{\text {th }}$ cent.

18. Vat. Syr. 274: Gospels, $10^{\text {th }}$ cent.

19. Vat. Syr. 275: Acts, Epistles, 1192

20. Vat. Syr. 278: Melkite lectionary, 9th cent.

21. Vat. Syr. 279: Melkite Gospel lectionary, 1141

22. Vat. Syr. 470: NT, $12^{\text {th }}$ cent.

23. Vat. Syr. 471: NT, 1224

24. Vat. Syr. 510: NT, $11^{\text {th }}$ cent.

25. Vat. Syr. 525: Gospel lectionary, $7^{\text {th }}$ cent. 
26. Vat. Syr. 532: Acts, Epistles, $13^{\text {th }}$ cent. 27. Vat. Syr. 556: Gospel lectionary, $13^{\text {th }}$ cent.

28. Vat. Syr. 559: Gospel lectionary, 1220 with illuminations

29. Vat. Syr. 622: Gospels written in gold letters, 1298

30. Barbarini or. 2: Pentaglot psalter, 14th cent.

31. Barbarini or. 3: Gospel lectionary, $13^{\text {th }}$ cent.

32. Borgia Syr. 14f-k: Gospel lectionary, 1254, with illuminations

33. Borgia Syr. 169: Gospel lectionary, 16 th cent. With illuminations

34. Borgia Syr. 117: Masora NT, 1014

\section{Literary Texts}

* indicates manuscript contains unpublished material.

35. Vat. Syr. 37: *Lives of Saints

36. Vat. Syr. 93: *John of Apamea, $9^{\text {th }}$ cent.

37. Vat. Syr. 100: *John of Dara, $19^{\text {th }}$ cent.

38. Vat. Syr. 103: $(*)$ Catena Severi

39. Vat. Syr. 104: Athanasius, 564 (*Timothy Alex.)

40. Vat. Syr. 105: Gregory of Nazianzus, Iambics, $7^{\text {th }}$ cent.

41. Vat. Syr. 106: *Gregory of Nyssa, $8^{\text {th }}$ cent.

42. Vat. Syr. 107: *John Chrysostom, hom. on John, $8^{\text {th }}$ cent.

43. Vat. Syr. 108: Peter of Callinicum, $8^{\text {th }}$ cent.

44. Vat. Syr. 109: *Abba Isaiah etc. 692

45. Vat. Syr. 110: Ephrem, Comm. Genesis, 523

46. Vat. Syr. 111: Ephrem, Hymns on Church etc. 522

47. Vat. Syr. 112: Ephrem, Hymns on Paradise, 551

48. Vat. Syr. 113: Ephrem, Hymns on Faith, 552

49. Vat. Syr. 114: *Jacob of Serugh, verse homilies, 523

50. Vat. Syr. 115: *Jacob of Serugh, verse homilies, $7^{\text {th }}$ cent.

51. Vat. Syr. 116: $\left(^{*}\right)$ Jacob of Serugh, verse homilies, 857

52. Vat. Syr. 117: *Jacob of Serugh, verse homilies, $12^{\text {th }} / 13^{\text {th }}$ cent.

53. Vat. Syr. 118: ${ }^{*} J a c o b$ of Serugh, verse homilies, pre-12 ${ }^{\text {th }}$ cent.

54. Vat. Syr. 119: *Isaac of Antioch, verse homilies, 1210

55. Vat. Syr. 120: *Isaac of Antioch, verse homilies, $6^{\text {th }}$ cent.

56. Vat. Syr. 121: *Mark the Hermit

57. Vat. Syr. 122: *Mark the Hermit, Basil, 769

58. Vat. Syr. 123: ${ }^{*}$ Gregory of Cyprus etc. $8^{\text {th }}$ cent.

59. Vat. Syr. 124: Isaac of Nineveh, $14^{\text {th }}$ cent.

60. Vat. Syr. 125: Isaac of Nineveh

61. Vat. Syr. 126: Paradise of the Fathers, 1223

62. Vat. Syr. 127: Canons of Councils 
63. Vat. Syr. 135: *Philoxenos etc. $7^{\text {th }} / 8^{\text {th }}$ cent.

64. Vat. Syr. 136: (*)Philoxenos $6^{\text {th }}$ cent.

65. Vat. Syr. 137: Philoxenos, 564

66. Vat. Syr. 138: Philoxenos, 581

67. Vat. Syr. 139: Severus, Philalethes etc, $8^{\text {th }}$ cent.

68. Vat. Syr. 140: Severus, against Julian, 528

69. Vat. Syr. 141: Severus, Cathedral homilies (tr. Jacob of Edessa)

70. Vat. Syr. 142: *Severus, Cathedral homilies (tr. Paul), 576

71. Vat. Syr. 143: *Severus, Cathedral homilies (tr. Paul), 563

72. Vat. Syr. 144: John, Arbiter etc.

73. Vat. Syr. 145: Elias, *Socrates Eccl. Hist., Zecharias Rhetor

Eccl. Hist. $9^{\text {th }} / 10^{\text {th }}$ cent.

74. Vat. Syr. 146: (*)John Maro, Liber Fidei, 1392

75. Vat. Syr. 147: *Moshe bar Kepha etc. 1234

76. Vat. Syr. 148: Ps. George of Arbela, Liturgical commentary, 1267

77. Vat. Syr. 151: (*)Timothy II, On Sacraments, 1613

78. Vat. Syr. 152: *Jacob of Edessa, on biblical names, 980

79. Vat. Syr. 154: *George, Com. Matthew, $10^{\text {th }}$ cent.

80. Vat. Syr. 157: Isho'yahb III, Letters, $10^{\text {th }}$ cent.

81. Vat. Syr. 160: Life of Symeon the Stylite, *Acts of Persian martyrs, $474,10^{\text {th }}$ cent.

82. Vat. Syr. 161: * Acts of Persian martyrs

83. Vat. Syr. 162: Ps. Dionysius of Telmahre, Chronicle, 932

84. Vat. Syr. 163: Chronicle of Edessa

85. Vat. Syr. 165: Thomas of Marga, Monastic history, 1663

86. Vat. Syr. 189: *John of Dalyatha, 11th cent.

87. Vat. Syr. 191: *Ibn Sina, Syriac tr.

88. Vat. Syr. 192: *Medical

89. Vat. Syr. 194: *Grammatical works, 1246

90. Vat. Syr. 251: *Jacob of Serugh, homilies, ${ }^{\text {th }}$ cent.

91. Vat. Syr. 252: Jacob of Serugh, homilies

92. Vat. Syr. 253: *Homiliary, $8^{\text {th }}$ cent.

93. Vat. Syr. 254: *Ps. Dionysius the Areopagite, pre-932

94. Vat. Syr. 255: Severus, pre-932

95. Vat. Syr. 256: *Severus, Cathedral homilies, $6^{\text {th }}$ cent.

96. Vat. Syr. 283: *Comm. Matthew and John, 860

97. Vat. Syr. 284: ${ }^{*}$ Comm. Epistles, 9th cent.

98. Vat. Syr. 367: Isaac of Nineveh, $8^{\text {th }}$ cent.

99. Vat. Syr. 368: *Homiliary, $8^{\text {th }}$ cent. 
100. Vat. Syr. 369: *Homiliary, 7 th cent.

101. Vat. Syr. 464: Ephrem, Isaac, Jacob of Serugh, 1234

102. Vat. Syr. 467: *Life of Hoseph Busnaya, 1186

103. Vat. Syr. 506: *Athanasius Abu Ghalib, 1927 (from an old MS)

104. Vat. Syr. 509: *Monastic texts, 1928 (from an old MS)

105. Vat. Syr. 560: Canon law, $8^{\text {th }}$ cent.

106. Vat. Syr. 581: *John of Dara, 1917 (from an old MS)

107. Vat. Syr. 586: *Questions and answers on Aristotle, Categories, 13th

cent.

108. Vat. Syr. 623: *Melkite Monastic texts, 886

109. Vat. Syr. 627: ${ }^{*}$ Fragment of Homiliary, $9^{\text {th }} / 10^{\text {th }}$ cent.

110. Vat. Syr. 628: *Fragment (1f) of Lifeof Abraham Qidunaya, $7^{\text {th }}$ cent.

111. Vat. Syr. 629: *Gregory of Cyprus, $12^{\text {th }}$ cent.

\section{Liturgical texts}

112. Vat. Syr. 42: East Syriac Euchologion, 1202

113. Vat. Syr. 51: West Syriac Pontifical of Michael the Patriarch, $12^{\text {th }}$ cent.

114. Vat. Syr. 53: Melkite Euchologion

115. Vat. Syr. 59: West Syriac funeral services, 1266

116. Vat. Syr. 60: West Syriac funeral services, $13^{\text {th }}$ cent.

117. Vat. Syr. 61: East Syriac funeral services, $13^{\text {th }}$ cent.

118. Vat. Syr. 68: West Syriac Beth Gaz:a, 1465

119. Vat. Syr. 78-82: Melkite Menaia, $12^{\text {th }} / 13^{\text {th }}$ cent.

120. Vat. Syr. 83: East Syriac Hudra, 1537/9

121. Vat. Syr. 92: Funeral services, 823

122. Vat. Syr. 95: Seblatha, $13^{\text {th }}$ cent.

123. Vat. Syr. 539: Husoye, $10^{\text {th }} / 11^{\text {th }}$ cent.

124. Borgia Syr. 13: Melkite Euchologion, $12^{\text {th }}$ cent.

125. Borgia Syr. 60: East Syriac Beth Gazza

126. Borgia Syr. 133 II: Seblatha, 13 ${ }^{\text {th }}$ cent.

127. Borgia Syr. 159: West Syriac anaphoras, 1295

128. Vat. Syr. 527: Canticles, $6^{\text {th }}$ cent. (2 folios) 